\title{
Microbiological Analysis of Major Sea Food Consumed in Coastal Area of Chennai, Tamil Nadu
}

\author{
S. Padmavathy and V. Gayathri* \\ Department of Microbiology, Ethiraj College for Women, Chennai- 600008, Tamil Nadu, India \\ *Corresponding author
}

A B S T R A C T

\begin{tabular}{|c|}
\hline Keywords \\
\hline $\begin{array}{l}\text { Catla, Malabar } \\
\text { trevally, Prawn, } \\
\text { Threadfin bream, } \\
\text { Mussels, Oyster and } \\
\text { faecal coliforms. }\end{array}$ \\
\hline Article Info \\
\hline $\begin{array}{l}\text { Accepted: } \\
19 \text { October } 2017 \\
\text { Available Online: } \\
10 \text { December } 2017\end{array}$ \\
\hline
\end{tabular}

The main source of microbial contamination of coastal waters is domestic waste water and sewage discharge. In this present investigation sea foods were collected from Ennore creek Chennai Coast. The sea foods like Catla, Malabar trevally, prawn, Threadfin bream, mussels and oysters were degutted and bacteria were isolated using selective and non-selective agar medium and further confirmed by biochemical tests. The organisms were identified to generic or group level according to Bergey's manual of systematic Bacteriology. Different group of fecal coliforms and Vibrio spp. have been isolated. Escherichia coli, Vibrio parahaemolyticus, Vibrio cholera, Staphylococcus aureus, Shigella dysentriae were the dominant species. Shell fishes ingest bacteria along with their feed which is dangerous to humans who eat the infected seafood. Sea food has to be handled, stored and processed properly.

\section{Introduction}

Today's world is witnessing the resurgence in the consumption of fish due to the new awareness about its low cholesterol, fat content and good quality of animal protein. Fish and other sea foods are among the most important protein rich foods for human beings especially in a country like India. Since consumption of raw or uncooked sea foods leads to a variety of diseases which are harmful. Water resources and its distribution system have the chances of pollution with various microorganisms, hospitals, farms and domestic sewages. The fishes and shellfishes living in this water sources are at risk of acquiring the antibiotic resistance. This may cause serious health hazards to human and animals especially in countries where the sanitary and hygiene measures are not up to the mark. Keeping in view the above points the present study was envisaged to study the occurrence of microorganisms in fishes and shellfishes from mogathuwara kuppam, Ennore -Chennai coastal region.

Ennore creek is a backwater located in Ennore, Chennai along the Coromandel Coast of the Bay of Bengal. It is located in the zone comprising lagoons with salt marshes and backwaters, submerged under water during high tide and forming an arm of the sea with the opening to the Bay of Bengal at the creek. The creek receives wastewater from 
numerous sources including untreated wastewater and treated effluents from industrial sources in the surrounding area. Studies reveal that permitted discharges account for less than $40 \%$ of the total BOD load measured in the creek. Heavy metal concentrations are found to be higher near the creek mouth compared with the near shore waters. Majority of heavy metal pollutants are likely to be present in a close proximity range of $0.5 \mathrm{~km}$ from the creek mouth after which there is a steady decline in their concentration up to $1.5 \mathrm{~km}$.

The pollution in backwater ecosystem resulting from sewage discharges is manifested by the presence and persistence of pathogenic bacteria. Water borne pathogens like Shigella sps, Salmonella sps and Vibrio sps show persistence in polluted marine and estuarine waters. Environmental surveys are necessary for understanding and documenting the occurrence and distribution of pollution indicator and human pathogenic bacteria. In order to quantify and understand their relationship with relevant environmental factors, several investigators have examined distribution of these groups of bacteria and certain viruses in coastal waters (Colwell et al., 1977; Marchand, 1986; Patti et al., 1987; Piccolomini et al., 1987; Ramaiah and chandramohan, 1993; Ruiz et al., 2000; Ramaiah and de, 2003). Mortality and survival rates of faecal contamination indicator Escherichia coli in the marine regimes have also been studied (Darakas, 2001). Further, different species of bacteria including pathogenic ones (Colwell et al., 1981; Xu et al., 1982; Huq et al., 1984; McCarthy and Khambaty, 1994; McCarthy et al., 1996; Wait and Sobsey, 2000; Darakas, 2001; Ramaiah et al., 2002a) survive in sea water for one to several weeks.

The impact of these indicator bacteria and pathogens on the fishery and coastal waters are significant since these organisms got ingested into the gut and alimentary canal of fishes, prawn and bivalves. In order to confirm the presence of pathogenic organisms present in the sea foods majorly consumed in Chennai coastal area such as fishes, prawns, oysters, mussels were microbiologically analysed.

\section{Samples collected}

Fish samples of Malabar trevally, catla, threadfin bream, mullet, oysters, prawns, and mussels were collected and analysed. The currently recommended method of monitoring shellfish for the presence of microbial pathogens requires culturing followed by a series of presumptive and confirmatory tests that can often take more than 5 days to complete (APHA, 1985; D'Aoust, 1989; Miescier et al., 1992).

\section{Materials and Methods}

\section{Isolation of bacteria}

A small piece of flesh or tissue was extracted from the sample and it was homogenised well with sterile distilled water using a sterile mortar and pestle. $1 \mathrm{gm}$ of the homogenate was suspended into a test tube containing sterile distilled water. The diluted sample was plated in Zobells marine agar and was incubated at $37^{0} \mathrm{C}$ overnight.

Isolation and Identification of Individual colonies from Zobell Marine Agar media were randomly selected and subcultured. After purification, the organisms were tested for Gram reaction, motility and Biochemical tests (IMViC), $\mathrm{H}_{2} \mathrm{~S}$ production, sucrose, lactose and mannitol fermentation. The organisms were identified to generic or group level according to Bergey's manual of systematic Bacteriology and (Baumann and Baumann, 1981). 


\section{Results and Discussion}

Out of the seven seafood sample collected from the Ennore estuary, the microorganisms present in it include Vibrio sps. (sample1, 3, 4, 5, 6, 7) and Staphylococcus sps. (sample 1,2,3,4,7) and several Enterobactericeae (sample 1,2,3,4,5,6,7) family (Table 1 and Fig. 1-5).

Sewage contamination of aquatic habitats is detected by enumerating the coliform groups of bacteria (Fujioka, 2002). As is universally accepted, higher sewage contamination would lead to increased number of coliforms in natural water bodies. Indiscriminate, deliberate, accidental or regular/routine disposals of sewage in most developing countries lead to higher abundance of coliform groups. Ecological surveillance for microbiological analysis is therefore necessary on a continuous basis for realizing the impacts of effluent discharges. Further, as innumerable pathogenic bacteria will constitute the microflora of effluents discharged from domestic, urban, agricultural and certain manufacturing practices, quantifying different groups of pathogenic prokaryotes ought to be a part of such surveys. For instance, information on occurrence, abundance and distribution of potent human pathogens Vibrio cholera (causing cholera in humans), Vibrio parahaemolyticus (gasteroenteritis), Salmonella and Shigella spp (typhoid fever; food poisoning), and Staphylococcal spps (causing skin infections) in aquatic ecosystem may prove useful in public health management (Nagvenkar and Ramaiah, 2009). Microbiologists rely on the principle that higher the incidence of sewage indicator bacteria in any environment, higher would be the chances for human pathogenic bacteria to be present (Brock et al., 1994; Fujioka, 2002). Further, bacterial metabolism is such that, if a particular group, say Vibrio cholerae is the dominant bacterium in the sewage discharges, it can compete and rapidly outgrow the native microflora leading to increased levels of indicator bacteria in natural water bodies. Pathogenic bacteria of human health concern have mostly been studied for their survival in the marine environment (Huq et al., 1984, Byrd and Colwell 1990; Smith et al., 1994; Oliver et al., 1985).

Pollution problems are encountered in Ennore estuary as it receives industrial effluents and domestic sewage mostly in untreated condition. These affect water quality and living organism. Major industries like Kothari chemicals, alkali chemicals, madras refineries, madras fertilizers, petrochemical industries, many other industries and government installations like Ennore Thermal power station are located around Ennore estuary. It has been estimated that about 4.49,000 litres / day of industrial effluents carrying heavy metals are let out in this estuary by the industrial establishments. Another source of pollution that poses danger of fishes and other aquatic life is the flow of domestic sewage and about 4million litres/day are discharged into this estuary, Tamilnadu water supply and sewerage board, report 1980 (Shanthi and Gajendran, 2009).

Even though the bar mouth of this estuary is kept open throughout the year by dredging operations by Ennore thermal power station for maintaining free flow of sea water into this estuary, a large number of fish, prawn and other organisms die every year in this estuary due to water contamination. The physiochemical characteristics of the water such as temperature, salinity, dissolved oxygen, $\mathrm{pH}$ and water transparency were the major cause for the presence of pathogenic microorganism in it which further makes entry into the sea foods (Ambrose et al., (1998). 
Samples collected

\begin{tabular}{|c|c|c|}
\hline Sample & Common Name & Scientific Name \\
\hline $\mathbf{1}$ & Malabar trevally & Carangoides malabaricus \\
\hline $\mathbf{2}$ & Mullet & Mugil cephalus \\
\hline $\mathbf{3}$ & Catla & Gibelion catla \\
\hline $\mathbf{4}$ & Threadfin bream & Nemipterus virgatus \\
\hline $\mathbf{5}$ & Prawn & Penaeus monodon \\
\hline $\mathbf{6}$ & Oyster & Crassostrea virginica \\
\hline $\mathbf{7}$ & Mussel & Perna viridis \\
\hline
\end{tabular}

Table.1 Predominant organisms in the sea food samples

\begin{tabular}{|l|l|l|l|}
\hline Samples & Organism Isolated & $\begin{array}{l}\text { Organism } \\
\text { Isolated }\end{array}$ & $\begin{array}{l}\text { Organism } \\
\text { Isolated }\end{array}$ \\
\hline $\begin{array}{l}\text { 1.MALABAR } \\
\text { TREVALLY }\end{array}$ & $\begin{array}{l}\text { Staphylococcus } \\
\text { aureus }\end{array}$ & Vibrio cholera & Shigella dysenteriae \\
\hline 2.MULLET & Salmonella enterica & $\begin{array}{l}\text { Staphylococcus } \\
\text { epidermidis }\end{array}$ & $\begin{array}{l}\text { Staphylococcus } \\
\text { aureus }\end{array}$ \\
\hline 3.CATLA & Vibrio cholerae & $\begin{array}{l}\text { Staphylococcus } \\
\text { aureus }\end{array}$ & Salmonella enteric \\
\hline $\begin{array}{l}\text { 4.THREADFIN } \\
\text { BEAM }\end{array}$ & $\begin{array}{l}\text { Staphylococcus } \\
\text { aureus }\end{array}$ & Escherichia coli & $\begin{array}{l}\text { Vibrio } \\
\text { parahaemolyticus }\end{array}$ \\
\hline 5.PRAWN & $\begin{array}{l}\text { Vibrio } \\
\text { parahaemolyticus }\end{array}$ & Shigella dysentriae & Vibrio cholerae \\
\hline 6.OYSTER & $\begin{array}{l}\text { Vibrio } \\
\text { parahaemolyticus }\end{array}$ & Salmonella enteric & Escherichia coli \\
\hline 7.MUSSEL & $\begin{array}{l}\text { Vibrio } \\
\text { parahaemolyticus }\end{array}$ & $\begin{array}{l}\text { Staphylococcus } \\
\text { aureus }\end{array}$ & Vibrio cholera \\
\hline
\end{tabular}

Fig.1 Vibrio cholera in TCBS agar

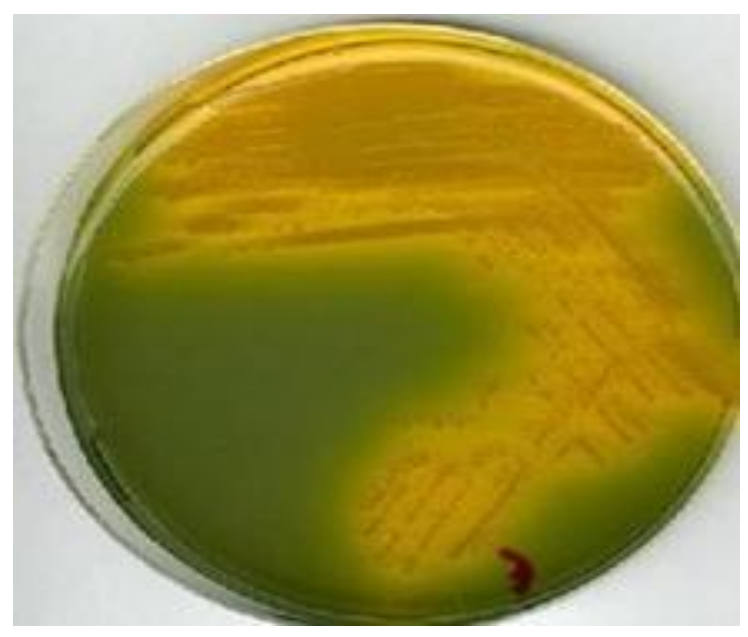


Fig.2 Escherichia coli in EMB agar

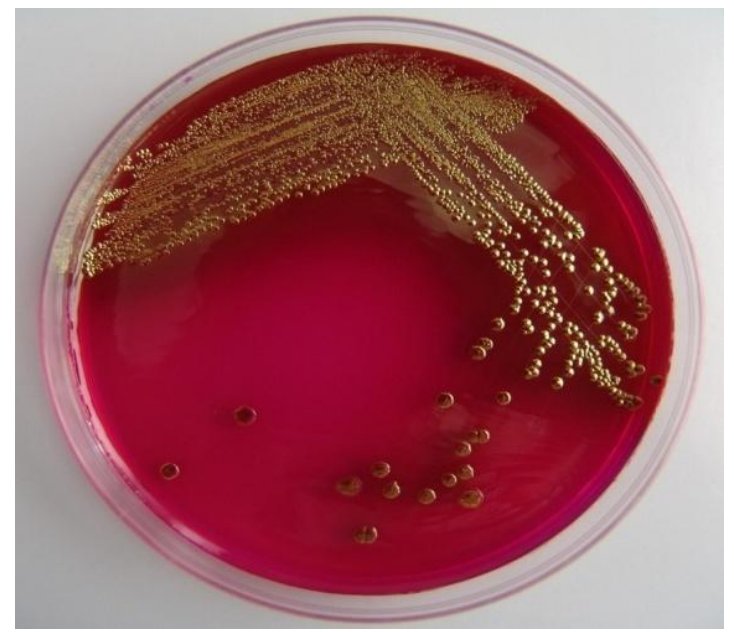

Fig.3 Staphylococcus aureus in Mannitol salt agar

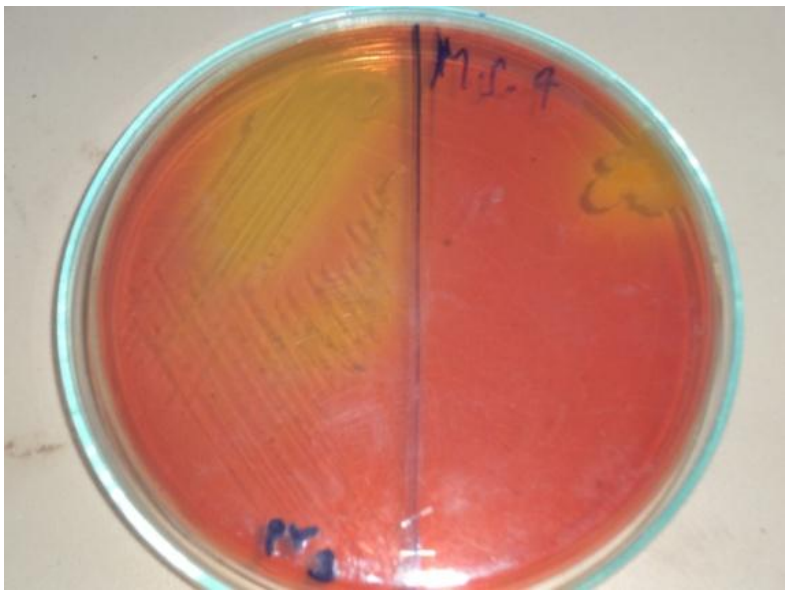

Fig.4 Salmonella enterica in SS agar

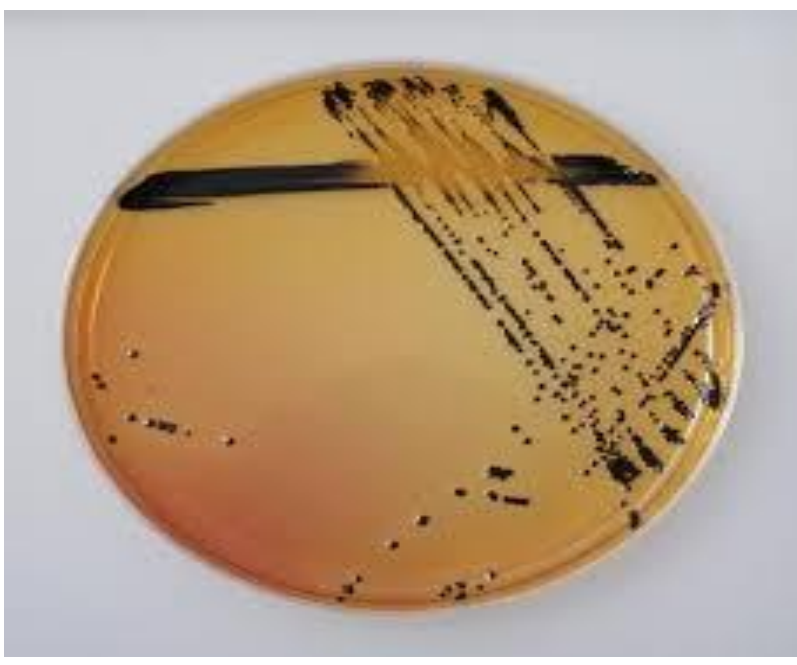


Fig.5 Vibrio parahaemolyticus in TCBS agar

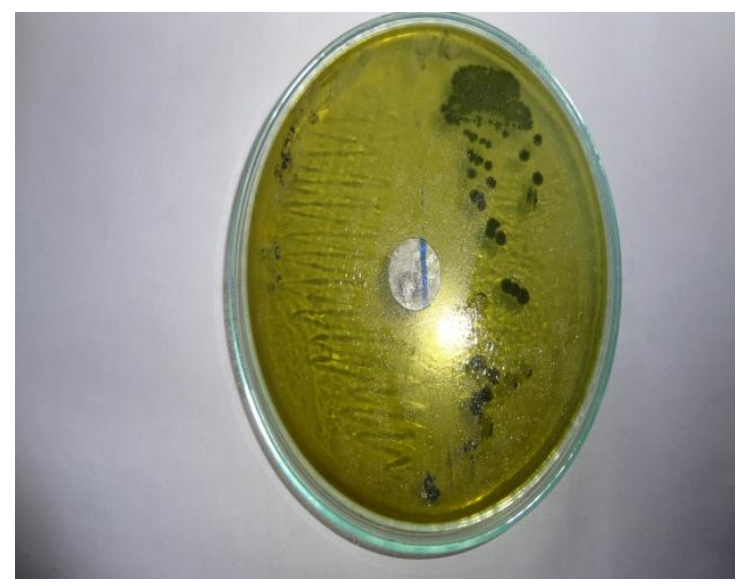

When these contaminated sea foods are consumed as raw or undercooked, we humans get several diseases.

The most pathogenic organism happens to be Vibrio sps. The genus Vibrio is gram negative, oxidase reaction positive, grow on TCBS agar (Fig. 1 and 5), oxidativefermentative test positive. Besides these characteristics, they also give reaction with arginine, lysine, ornithine, amylase, indole, citrate, Voges-Proskauer, urease, gelatin, growth on 0,6 , and $8 \% \mathrm{NaCl}$, growth at temperature 4,35 and $40^{\circ} \mathrm{C}$, resistance with $\mathrm{O} / 129 \mu \mathrm{g}$, produce acid from some sugars, etc. The genus Staphylococcus is a gram positive, catalase positive, grow on MSA agar, hydrolyse urea, reduce nitrates to nitrites, liquefy gelatin. Besides these they are coagulase positive, greater biochemical activity; ferment mannite, produce clear haemolysis on blood agar, produce phosphatase, in a medium containing potassium tellurite, reduce tellurite to form black colonies (Alsina and Blanch, 1994a).

Vibrio parahaemolyticus is a marine bacterium that occurs naturally in shellfish, oyster, prawn, crab, raw fish, blue mussels, fresh water fish, sea fish, etc. fish is a good protein source and Chennai is one of the places in India where consumption is very high (Beuchat, 1982). In Chennai some of the fish variety is delivered from other states of India. Moreover this bacterium is commonly found in other South East Asian countries.

Vibrios constitute a major portion of the micro biota in brackish water pond ecosystem. In shrimp farms from India, (Otta et al., (1999) and Vaseeharan and Ramasamy (2003) noted that vibrio species accounted for $38-81 \%$ of the bacterial biota. In this study, the edible sea food samples analysed were found to contain Staphylococcus spp, Enterobactericeae spp and vibrio species of which Vibrio parahaemolyticus is an organism of concern not only because some strains of this species were associated with diseases in sea foods but also because some strains of this species are human pathogens, causing gasteroenteritis (Saqkazaki et al., 1968; Honda et al., 1987; Farmer and Hickman-Brenner, 1992; Powell, 1999). The natural habitat of vibrio spp is estuarine and marine water and sediment. Vibrios often occur in association with invertebrate and vertebrate animal surfaces and internal organs (Huq et al., 1983; Grimmes et al., 1984b). Stress can compromise the animal host resulting in a commensal species switching to pathogenicity as the mode of interaction (Grimmes et al., 1984c). Out of the 7 seafood samples from Chennai coastal region tested 
for presence of marine pathogens, 4 samples were found to be positive for vibrio parahaemolyticus. This percentage is in agreement with other studies that reported about $50-70 \%$ of seafood showed the presence of vibrio parahaemolyticus (Fletcher, 1985; Linda et al., 2006). Earlier works of Sakazaki et al., (1968) reported that $1-2 \%$ of environmental samples contain virulent isolates. Recently Deepanjali et al., reported that the environmental samples (oysters) contain $\quad 93.87 \% \quad$ Vibrio parahaemolyticus in south west coast of India. In this study it is further more confirmed that the sea food seemed to contain vibrio species which are pathogenic to human due to the pollution of water resources. So in order to ensure a good and hygienic seafood, pollution of water resources should be avoided which is achieved by proper treatment of effluents from factories and sewage which treat waste water to remove major pathogenic organisms. Upon ensuring the above mentioned two strategies, pollution of sea water can be prevented and seafoods becomes safe for humans to be consumed.

\section{References}

Alsina M and Blanch A R 1994 A set of keys for biochemical identification of environmental Vibrio species. Journal of Applied Bacteriology Volume 74, pp7985.

Alsina M, Blanch AR (1994a). A set key for biochemical identification of environmental Vibrio species. J. Appl. Bacteriol. 76: 79-85.

Ambrose, R.B., Connly, J.P., Southerland, E., Branwell, T.O. and S Schnoor, J.L. (1998), Waste load allocation models (WLA). J. Water pollution control federation, 60(9): 1646-1956.

American Public Health Association (1985) Recommended Procedures for the Examination of Sea Water and Shellfish $4^{\text {th }}$ edn pp. 9 \pm 210 . Washington DC:
American Public Health Association.

Baumann, P. and Baumann, L. (1981). The Marine Gram-Negative Eubacteria: Genera Photobacterium, Beneckea, Alteromonas, Pseudomonas, and Alcaligenes. Berlin: Springer.

Beuchat L R 1982 Vibrio parahaemolyticus: Public health significance. Food Technology, Volume 25 pp80-83.

Brock, T., Madigan, M.T., Martinko, J.M. and Parker, J. (1994). Biology of Microorganisms (Seventh Edition)', Prentice hall, New Jersey.

Byrd, J. J. and Colwell, R. R. (1990). Maintenance of plasmids pBR322 and pUC8 in non-culturable Escherichia coli in the marine environment. Applied and Environmental Microbiology. 56, 21042107.

Colwell, R.R., Kaper, J. and Joseph, S.W. (1977). Vibrio cholerae, Vibrio parahaemolyticus, and other Vibrios: Occurrence and distribution in Chesapeake Bay. Science, 198, 394-396.

Colwell, R.R., Seidler, R.J., Kaper, J., Joseph, S.W., Garges, S., Lockman, H., Maneval, D., Bradford, H., Roberts, N., Remmers, E., Huq, I and Huq, A. (1981). Occurrence of Vibrio cholera serotype O1 in Maryland and Lona estuaries. Applied and Environmental Microbiology, 4, 555558.

D'Aoust, J. (1989) Salmonella spp. In Foodborne Bacterial Pathogens. Doyle M.P. (Ed), pp. 327 \pm 445 . New York, NY: MarcelDekker Inc.

Darakas, E. (2001). A simple mathematical formula describing the survival kinetics of Escherichia coli in natural waters. International Journal of Environmental Studies, 58, 365-372.

Farmer, J.J., III and Hickman- Brenner, F.W. (1992). The genera Vibrio and photobacterium. In the Prokaryotes, $2^{\text {nd }}$ edn, pp. 2952- 3011. Edited by A. Balows, H.G. Truper, M. Dworkin, W. Harder and K.H. Schleifer. Heidelberg: Springer. 
Fletcher, G.C.1985. The potential food poisoning hazard of Vibrio parahaemolyticus in New Zealand Pacific Oysters. New Zealand Journal of Marine and Freshwater Research 19: 495-505.

Fujino, T., Y. Okuno, D. Nakada, A. Aoyoma, K. Fukai, T. Mukai, and T. Ueho. 1953. On the bacteriological examination of shirasu food poisoning. Med. J. Osaka Univ. 4:299-304.

Fujioka, R. (2002). Microbial indicators of marine recreational water quality. In: Manual of Environmental Microbiology, Second edition. (eds: Hurst, C.J., Crawford, R.L., Knudsen, G., McIneney, M. J. and Stetzenbach, L. D.), American Society for Microbiology Press, Washington DC, Pp. 234-243.

Nagvenkar, G.S. and N. Ramaiah, 2009. National Institute of Oceanography, Goa. Abundance of sewage- Pollution indicator and human pathogenic bacteria in a tropical estuarine complex. Author version: Environ. Monit. Assess., 155 (14): $245-256$.

Grimes, D. J., Cowell, R. R., Stemmler, J., Hada, H., Maneval, D., Hetrick, F. M., May, E. B., Jones, R. T. and Stoskopf, M., 1984b. Vibrio species as agents of elasmobranch disease. - Helgoländer Meeresunters. 37: 309-315.

Grimes, D. J., Gruber, S. H. and May, E. B., 1984c. Experimental infection of lemon sharks, Negaprion brevirostris, with Vibrio species. - J. Fish Dis. (Submitted).

Honda, K., Yamamoto, Y., Kato, H. and Tatsukawa, R. (1987): Heavy metal accumulations and their recent changes in southern minke whales Baraenoptera acutorostrata. Arch. Environ. Contam. Toxicol., 16, 209-216.

Huq, A., West, P.A., Small, E.B. and Colwell, R.R. (1984) Influence of water temperature, salinity and $\mathrm{pH}$ on survival and growth of toxigenic Vibrio cholerae serovar $\mathrm{O} 1$ associated with live copepods in laboratory microcosms. Applied and Environmental Microbiology, 48, 420-
424.

Linda, N.W. and Asim, K.b. 2006. Detection of Vibrio parahaemolyticus in shellfish bye use of multiplexed PCR with TaqMan Fluorescent Probes. Applied and Environmental Microbiology 72: 20312042.

Marchand, M. (1986). 'Ecological Study of Vibrios in Arcachon Bay Second International Colloquium on Marine Bacteriology, Brest, 1-5, October 1984. Gerbam, CNRS, IFREMER, France, 3, 483-489.

McCarthy, S.A. and Khambaty, F.M. (1996). International dissemination of epidemic Vibrio cholerae by cargo ship ballast and other non-potable waters. Applied and Environmental Microbiology, 60, 25972601.

Miescier, J.J., Hunt, D.A., Redman, J., Salinger, A. and Lucas, J.P. (1992) Molluscan shellfish: oysters, mussels and clams. In Compendium of Methods for the Microbiology Examination of Goodsed. Vanderzant, C. and Splittstoesser, D.F. pp. $897 \pm 918$.

Oliver, J. D., Hite, F., McDougald, D., Andon, N. L. and Simpson, L. M. (1995). Entry into and resuscitation from, the viable but non-culturable state by Vibrio vulnificus in an estuarine environment. Applied and Environmental Microbiology, 61, 26242630.

Otta SK, Shubha G, Joseph B, Chakraborty A, Karunasagar I, Karunasagar I (1999) Polymerase chain reaction (PCR) detection of white spot syndrome virus (WSSV) in cultured and wild crustaceans in India. Dis Aquat Org 38: 67-70.

Patti, A.M., Paroli, E., Gabrieli, R., D Angelo, A.M., De-Filippis, P., Villa, L. and Pana, A. (1987). Enteroviruses recovery from seawater: Statistical correlation with usual and chemical parameters, Ig. Mod. 87, 226-243.

Piccolomini, R., Cellini, L., Allocati, N., Gentili, E., Sartorelli, M. and DiGirolamo, A. (1987) Microbiological pollution of seawater, Ig. Mod. 87, 543- 
552.

Powell, J.L., 1999.Vibrio species. Clinical Laboratory Medicine 19,537-552.

Ramaiah, N. and Chandramohan, D. (1993). Ecological and laboratory studies on the role of luminous bacteria and their luminescence in the coastal pollution surveillance. Marine Pollution Bulletin, 26, $190-201$.

Ramaiah, N. and De, J. (2003). Unusual rise in mercury resistant bacteria in coastal environments. Microbial Ecology, 45, 444-454.

Ramaiah, N., Ravel, J., Straube, W.L., Hill, R.T. and Colwell, R.R. (2002a). Entry of Vibrio harveyi and Vibrio fischeri into the viable and non-culturable state. Journal of Applied Microbiology, 93, 108-116.

Ramaiah, N., Kenkre, V.D. and Verlecar, X.N. (2002b). Marine environmental pollution stress detection through direct viable counts of bacteria. Water Research, 36, 2383-2393.

Ruiz, G.M., Rawlings, T.K., Dobbs, F.C., Drake, L.A., Mullady, T., Huq, A. and Colwell, R.R. (2000). Global spread of microorganisms by ships. Nature, 408, 49-50.

Sakazaki, R., Tamura, K., Kato, T., Obara, Y., Yamai, S. and Hobo, K. (1968) Studies of the enteropathogenic, facultatively halophilic bacteria, Vibrio parahaemolyticus. III. Entero pathogenicity. Japanese Journal of Medical Science and Biology, 21, 325331.
Shanthi V., and N. Gajendran 2009. The impact of water pollution on the socio-economic status of the stakeholders of Ennore creek, Bay of Bengal (India): part 1 vol2 no3.

Singleton P (1999). Bacteria in Biology, Biotechnology and Medicine (5th ed.). Wiley. pp. 444-454.

Smith, J. J., Howington, J. P. and McFeters, G. A. (1994). Survival, physiological response, and recovery of enteric bacteria exposed to a polar environment. Applied and Environmental Microbiology, 60, 2977-2984.

Vaseeharan, B., Ramasamy, P., 2003 Abundance of potentially pathogenic microorganisms in Penaeus monodon larvae rearing systems in India. Microbiol Res 158: 299-308.

Wait, D.A. and Sobsey, M.D. (2000). Comparative survival of enteric viruses and bacteria in Atlantic Ocean seawater. Water Science and Technology, 43, 139142.

Washington DC: American Public Health Association. Nutrition_Facts and Analysis for_Molluscs,_oyster, eastern, wild, raw. Nutritiondata.com. Retrieved 2011-08-16.

Xu, H.S., Roberts, N., Singleton, F.L., Attwell, R.W., Grimes, D.J. and Colwell, R.R. (1982). Survival and viability of nonculturable Escherichia coli and Vibrio cholerae in the estuarine and marine environment. Microbial Ecology, 8, 313323.

\section{How to cite this article:}

Padmavathy, S. and Gayathri, V. 2017. Microbiological Analysis of Major Sea Food Consumed in Coastal Area of Chennai, Tamil Nadu, India. Int.J.Curr.Microbiol.App.Sci. 6(12): 2689-2697. doi: https://doi.org/10.20546/ijcmas.2017.612.311 